\title{
La presencia del cómic en el 45 Salón Nacional de Artistas de Colombia
}

\author{
Juan Alberto Conde Aldana y Diana Paola Gil Guzmán
}

\author{
Recibido:15.09.2021 — Aceptado: 31.10.2021
}

\section{Titre / Title / Titolo}

La présence de la bande dessinée dans le 45 Salon National des Artistes de Colombie

The presence of comic in the $45^{\text {th }}$ National Salon of Artists of Colombia La presenza del fumetto al $45^{\circ}$ Salone Nazionale degli Artisti della Colombia

\section{Resumen / Résumé / Abstract / Riassunto}

La incorporación del cómic en las exposiciones artísticas es un campo en expansión. En Colombia, la adaptación museística más relevante de la historieta aconteció en el 45 Salón Nacional de Artistas, el revés de la trama, que abrió algunos espacios expositivos al cómic en las curadurías Arquitecturas narrativas, Llamitas al viento y Contrainformación. En este artículo proponemos una aproximación a estas tres exposiciones según las conceptualizaciones del cómic y el espacio que cada una de ellas ofrece. En Arquitecturas narrativas se puede ver el paralelo entre la gestión del espacio en el bidimensional de la página y el tridimensional de la exposición. En Llamitas al viento se observa la inclusión del cómic en el ámbito de las publicaciones artísticas y la alternancia entre curaduría de textos y diseño de exposición. Y en Contrainformación, la resignificación de los cómics que provienen del auge de los movimientos sociales y campesinos de la década de los setenta, y de una historieta nueva comisionada para la muestra.

L'inclusion de la bande dessinée (BD) dans des expositions d'art est un domaine en pleine croissance. En Colombie, l'adaptation muséale le plus pertinent de la BD a eu lieu au 45e Salon National des Artistes, intitulé El revés de la trama (l'inverse de l'intrigue), qui a ouvert des espaces d'exposition pour la BD dans les commissariats des expositions Arquitecturas narrativas (Architectures narratives), Llamitas al viento (Flammes au vent) et Contrainformación (Contre-information). Dans cet article nous proposons une approche de ces trois expositions, selon les conceptualisations de la $\mathrm{BD}$ et de l'espace d'exposition que chacune d'elles propose. On décrira : dans Arquitecturas narrativas, le parallèle entre la gestion de l'espace dans la mise en page (bidimensionnelle) et la tridimensionnalité de l'espace d'exposition. Dans Llamitas al viento, l'inclusion de la BD dans le champ des publications artistiques et l'alternance entre commissariat de textes et scénographie. Et dans Contrainformación, la re-signification de la BD produite dans le cadre des mouvements sociaux des années 70 et d'une BD contemporaine commandée pour l'exposition.

Incorporating comics into art exhibits is a growing field. In Colombia, the most relevant museum adaptation of the comic took place at the 45 th $\mathrm{Na}$ tional Salon of Artists, The Fabric of Reversal, which opens some exhibition spaces to comic in the curatorship Narrative Architectures, Little Flames to the Wind and Counterinformation. In this article we propose an approach to these three exhibitions, according to the conceptualizations of the comic and the exhibition space that each one of them offers: in Narrative Architectures, the parallel between the management of space in the two-dimensional of the page and the three-dimensional of the exhibition; in Little Flames to the Wind, the inclusion of comics in the field of artistic publications and the alternation between curating texts and exhibition design; in Counterinformation, the resignification of comics originating from the rise of the social and peasant movements of the seventies and of a comic commissioned for the exhibition.

Incorporare i fumetti nelle mostre d'arte è un'area in crescita. In Colombia, l'adattamento museale più rilevante del fumetto si è svolto al $45^{\circ}$ Salone Nazionale degli Artisti, Il rovescio della trama, che apre alcuni spazi espositivi al fumetto all'interno delle curatela Architetture narrative, Fiammelle al vento e Controimformazione. In questo articolo proponiamo un approccio a queste tre mostre, secondo le concettualizzazioni del fumetto e dello spazio espositivo che ognuna di esse offre: in Architetture narrative, il parallelo tra la gestione dello spazio nella pagina bidimensionale ed esposizione tridimensionale; in Fiammelle al vento, l'inserimento del fumetto nell'ambito delle pubblicazioni artistiche e l'alternanza tra curatele di testi e scenografia espositiva; e in Controinformazione, la risignificazione del fumetto risultante dall'ascesa dei movimenti sociali e contadini negli anni setanta e di un fumetto commissionato per la mostra.

\section{Palabras clave / Mots-clé / Key words / Parole chiave}

Cómic de exposición, curaduría, 45 Salón Nacional de Artistas, campos artísticos, diseño expositivo.

BD d'exposition, commissariat d'exposition, 45 Salon nationale des artistes, champs artistiques, scénographie d'exposition.

Exhibition comic, curatorship, $45^{\text {th }}$ National Salon of Artists, artistic fields, exhibition design.

Mostra di fumetti, curatela, 45 Salone Nazionale degli Artisti, campi artistici, disegno espositivo. 


\section{Introducción}

La inclusión del cómic en los espacios de exposición tiene antecedentes desde principios del siglo XX, y se ha hecho más común con el cambio de siglo. La tradicional reticencia a que la historieta fuera presentada como objeto artístico y no exclusivamente como forma menor de expresión popular o masiva (Beaty, 2012), empieza a ser superada en el siglo XXI, con su mayor presencia en museos, galerías y otros espacios del arte contemporáneo.

Esto se explica, en gran medida, por las mutaciones dentro del campo del arte y, en particular, la disolución de las fronteras entre «alta cultura» y «arte de masas» operada durante las postvanguardias como el caso del arte pop o el apropiacionismo, que condujeron a una reformulación de las posibles incursiones del cómic en el arte contemporáneo (Groensteen, 2013) ${ }^{1}$. Y aunque la discusión sobre su legitimidad cultural sigue abierta (Meón, 2019), y aún hoy en día da lugar a diversas polémicas ${ }^{2}$, su presencia en los espacios expositivos no se detiene. Diferentes académicos (Beaty, 2012; Gravett, 2013; Munson, 2020) documentan y reconocen la importancia de lo que se ha dado en llamar el cómic de exposición. Exposiciones museísticas pioneras como Bande Dessinée et Figuration Narrative (Museo de las Artes Decorativas de París, 1967) y High \& Low: Modern Art and Popular Culture (Museo de Arte Moderno de Nueva York, 1990) ya planteaban diversas maneras de desplegar el cómic en las salas de los museos (Munson, 2009)3.

Colombia no ha sido ajena a la expansión del cómic de exposición. Desde hace varios años es notoria su presencia en diferentes espacios como ferias, festivales, galerías, museos, universidades, bibliotecas y casas de cultura. Los mayores esfuerzos expositivos se han hecho en el espacio de los festi-

En el contexto colombiano, el artista más representativo de la apropiación del cómic desde las prácticas artísticas contemporáneas es Álvaro Barrios, también conocido por ser pionero del arte conceptual en este país, quien ha explorado la relación arte/cómic en sintonía con el arte pop. Véase: https://yaizatranche.wordpress. com/2017/03/31/el-comic-de-alvaro-barrios-en-la-coleccion-de-la-fcdp/

Baste recordar, en el contexto español, la polémica suscitada por la declaración de Nuria Enguita en 2020, cuando asumió la dirección del IVAM, en la que ponía en duda la consideración del cómic como arte y su inclusión en las exposiciones del museo, lo que dio lugar a diversas reacciones por parte del sector del cómic, representadas principalmente en la Carta Abierta redactada por Antonio Altarriba. Véase: https://www.elcomicesarte.com/index.php/blog/

A este respecto, ha sido ampliamente reconocida la I Exposicao Internacional de Historias em Quadrinhos, a cargo de Álvaro Moya, llevada a cabo en el Centro Cultura e Progresso de Sao Paulo, Brasil, en 1951, como la pionera en consagrar al cómic una exposición museística, mucho antes que las de París o Nueva York (De Moya, 98-103). vales de cómic, como el Festival Internacional Calicomix y el Festival Entreviñetas. El primero empezó en 1994, como el Salón de Historieta y Caricatura en Cali, y el segundo en 2010 en Armenia. Ambos festivales no solo se centran en charlas y talleres, sino también en exposiciones sobre el trabajo de varios de los historietistas invitados a cada versión. Así mismo, en el contexto de Bogotá, espacios como la Fundación Gilberto Alzate Avendaño o la Cámara de Comercio de Bogotá han abierto sus salas de exposición a artistas de cómic como Rodolfo León Sánchez (2005) y Jean Paul Zapata (2013). Además, dibujantes de cómics colombianas, como Paola Gaviria (Powerpaola), han participado en exposiciones de historietas en otros países, como en la muestra Chicks on Comics en la Fundación PROA de Buenos Aires, Argentina (2016-2017).

Este incremento de la presencia del cómic en espacios museográficos encuentra su manifestación más relevante en el 2019, cuando el 45 Salón Nacional de Artistas (de aquí en adelante 45SNA), uno de los eventos artísticos más importantes en el contexto nacional, lo incluyó como parte de tres de las once curadurías que conformaron su más reciente versión. El SNA se inició en 1940 y su periodicidad ha sido irregular: desde lo anual hasta lo trienal. En su comienzo siguió el formato de los clásicos salones de arte europeos. Durante mucho tiempo el SNA funcionó como una convocatoria con jurados, con la adjudicación de un premio principal, para luego realizar la selección de los artistas a través de convocatorias y becas gestionadas por organismos de las administraciones locales. Los Salones Nacionales se crearon, así, como espacios de exposición, auspiciados por el Estado, para incluir diferentes prácticas del campo artístico.

Entre el 14 de septiembre y el 4 de noviembre de 2019, la ciudad de Bogotá volvió a ser la anfitriona del 45SNA, luego de cuatro versiones del evento en otras ciudades del país. En este salón, el concepto de El revés de la trama — que le da su título— funciona como el eje que estructuró las once propuestas curatoriales. Dicha fórmula se lee en varias direcciones, de acuerdo con su director artístico Alejandro Martín Maldonado (2019). De una parte, se trata de una metáfora espacial, que juega con el hecho de que el salón

fue pensado para el centro de Bogotá, donde la trama colonial tiene aún una presencia fuerte, como una rígida cuadrícula que se impuso sobre el territorio estableciendo nuevas formas de poder e intentando borrar los modos anteriores de habitarlo. Es una trama que se ha mantenido a pesar de los muy distintos 
momentos que ha vivido el país y que han dejado huella en la composición urbana, con capas y capas de historia que todavía se pueden leer allí. (13)

Esta «trama colonial» es constitutiva del centro de la ciudad, área donde se distribuyeron las once curadurías. Así mismo, la trama se entiende en sus diferentes acepciones como un verbo que sugiere ideas activas: intrigar, confabular, engatusar o enredar. De otra parte, el revés hace alusión a lo que no se muestra; al revés de los relatos, sus complejidades y contradicciones; y el revés como otras formas de organizarse (Martín, 14-17). Ambos conceptos hacen alusión a campos semánticos como lo urbanístico, lo narrativo y lo textil. El título, más que ser una camisa de fuerza para los curadores, fue una invitación a fijar la mirada desde otro lugar.

En este artículo nos proponemos examinar tres de las once curadurías del 45SNA, aquellas que incorporaron el cómic en sus museografías. Primero nos enfocaremos en $A r$ quitecturas narrativas, por ser la exposición que se pensó desde los mecanismos narrativos del cómic y su relación con la arquitectura. Luego estudiaremos Llamitas al viento, la curaduría de publicaciones del salón. Por último, en Contrainformación abordaremos cuatro cómics que se inscriben en microhistorias, tres de los cuales provienen de la década de los setenta y el cuarto fue comisionado para la muestra.

\section{El espacio expositivo como un cómic: Arquitecturas narrativas}

Arquitecturas narrativas fue la curaduría más ambiciosa en su incorporación del cómic. La exposición se desarrolló en el Centro Colombo Americano y estuvo a cargo del curador Alejandro Martín Maldonado, quien ya había trabajado exposiciones de cómic. Al ser también el director artístico del 45SNA incorporó la metáfora espacial de la trama urbanística y arquitectónica en su curaduría específica, que se planteó como una interacción entre dos formas de arte: el cómic y la arquitectura. Dicha relación la trazó así:

Esta exposición piensa la trama de la página del cómic./ Interesan los modos como se articulan tiempo y espacio allí/ Cómo se leen las viñetas, cómo se estructuran./Cómo se escribe, cómo se diseña, cómo se captura el tiempo en el espacio./Para pensar también la exposición como formato./La semiótica del cómic al servicio de la curaduría, de la museografía./Reconocer también cómo desde el cómic se piensa la arquitectura./Cómo se capturan los espacios./Las habitaciones./La ciudad. (164)

Aunque el título de la exposición y el propósito curatorial evocan la tesis doctoral de Enrique Bordes (Cómic, arquitectura narrativa, 2017), el planteamiento del curador no se centró exclusivamente en exponer páginas donde el espacio se concibe como una estructura arquitectónica, sino que jugó con las asociaciones entre espacio, viñeta, página, muro, lugar, de manera abierta y libre. De esta manera, se incluyeron diferentes objetos museísticos como bocetos, páginas originales o impresiones en gran formato, para mostrar la arquitectura de la página y la arquitectura de la ciudad. Además, según testimonio directo del propio curador, pensó la exposición «desde los cómics, pero no desde una idea exclusivista de los cómics» (Martín, entrevista por correo electrónico, 20 de enero de 2021). Es así como las superficies del espacio expositivo fueron ocupadas también por otro tipo de objetos de arte como la escultura, aunque siempre tratando de asimilarlos a las formas espaciales de la historieta.

A partir de esas ideas, y apuntando a los postulados de El revés de la trama, el curador seleccionó a nueve artistas para la muestra. En la nómina de historietistas hubo locales y extranjeros. Miguel Vallejo (Gusanillo) ${ }^{4}$ y Powerpaola ${ }^{5}$ participaron con páginas originales de algunas de sus historietas o ampliaciones de sus viñetas (en el caso del primero). Estos trabajos tienen en común que dibujan la arquitectura como fondo de sus narraciones, pero con énfasis distintos. El primero se enfoca en dibujar la urbe (figura 1) y la segunda en los decorados y espacios de la casa (figura 2). Con esa misma idea la curaduría incluyó algunos dibujos de la diseñadora gráfica y artista plástica Mónica Naranjo Uribe ${ }^{6}$ que trazan, alternadamente, la ciudad y espacios interiores. En este caso

\footnotetext{
Gusanillo es un joven historietista colombiano que ha publicado algunos cómics como Emok y el lobo (2017), Pollito Karateka (2019) y Sueños pictóricos (2020). En 2018 recibió un accésit en el II Premio de Novela Gráfica Ciudades Iberoamericanas por la obra Basuras, publicada por el sello Cohete Cómics en 2021. Véase: https:/ /www. behance.net/gusanillodetierra

Powerpaola es una reconocida ilustradora e historietista colombo-ecuatoriana. Ha publicado las novelas gráficas Virus Tropical (2011), qp (2014), Todo va a estar bien (2015), entre otras. Integra el colectivo de cómic internacional Chicks On Comics. Véase: http://powerpaola.blogspot.com/

Mónica Naranjo es una dibujante colombiana y autora de libros de artistas como La distancia entre extraños (2012) y Afuera y adentro (2014). Su trabajo ha sido expuesto en diferentes países. Véase: https://www.monicanaranjou.info/about/
} 


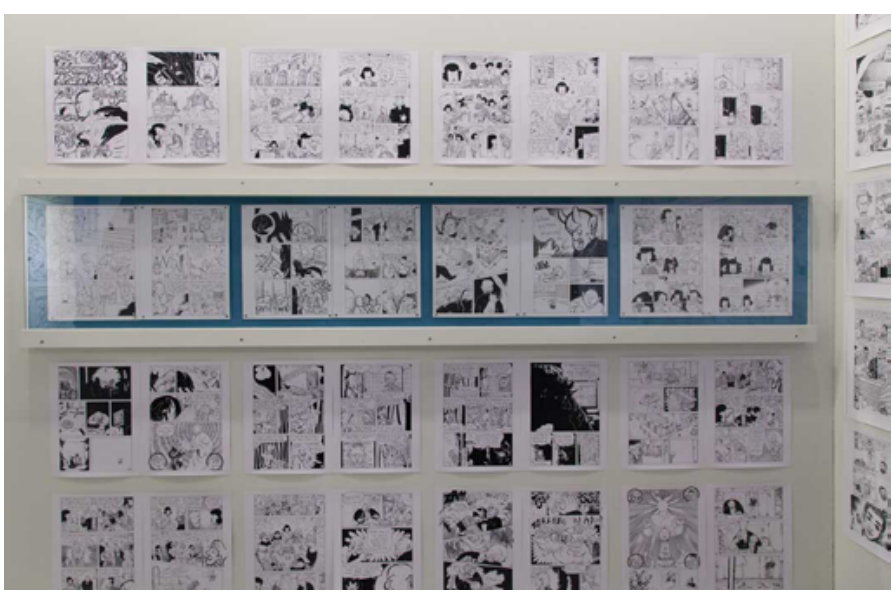

Figura 1. Originales de Gusanillo. Fuente: 45SNA - Colombia / MinCultura / Alcaldía de Bogotá, catálogo web, 2019.

las imágenes expuestas son impresiones, ya que la dibujante las elaboró directamente en soporte digital.

Para evocar «la concepción de la página como una estructura que hay que diseñar, similar a la arquitectura» (Bordes, 180), se expusieron originales del caleño Luis Tobón (Luto) y del estadounidense Ronald Wimberly. Luto es un artista gráfico, dibujante y grabador con gran reconocimiento en la historieta colombiana ${ }^{7}$ y sus páginas de Viñetero son las que más apuntan a la arquitectura de la página por la exploración y composición de los elementos gráficos del cómic (viñetas, bocadillos y diseño de página). Así mismo, su cómic en proceso, Mujer gorila, que el artista elaboró para la exposición, guarda una fuerte relación con la trama urbanística de Cali (figura 3), y también incorporó otro tipo de objeto museístico relacionado con el revés de la creación: un conjunto de figuras de personajes gráficos esculpidos en gomas de borrar, a manera de sellos de impresión. En el caso de Ronald Wimberly, historietista e ilustrador, se expusieron bocetos y originales de distintos cómics que redistribuyen espacios y acomodan geometrías como un proceso arquitectónico, provenientes de historietas que reflexionan sobre la relación del espacio urbano con la presencia y la lucha por el reconocimiento de las comunidades afrodescendientes en Norteamérica, y su lugar en la narración gráfica.

Además, se incluyeron otra serie de artistas por los distintos modos en que han trabajado el interior de la página o

A esta fecha, Luto ha publicado varios fanzines y tres libros de cómic: Viñetero (2017), Pogo de manos es de villanos. El libro de Carefukyou (2020) y Fuerte como la mugre (2021). Además, su trabajo ha aparecido en revistas como Carboncito (Perú) y Larva (Colombia). Véase: http://lutocorps.blogspot.com/

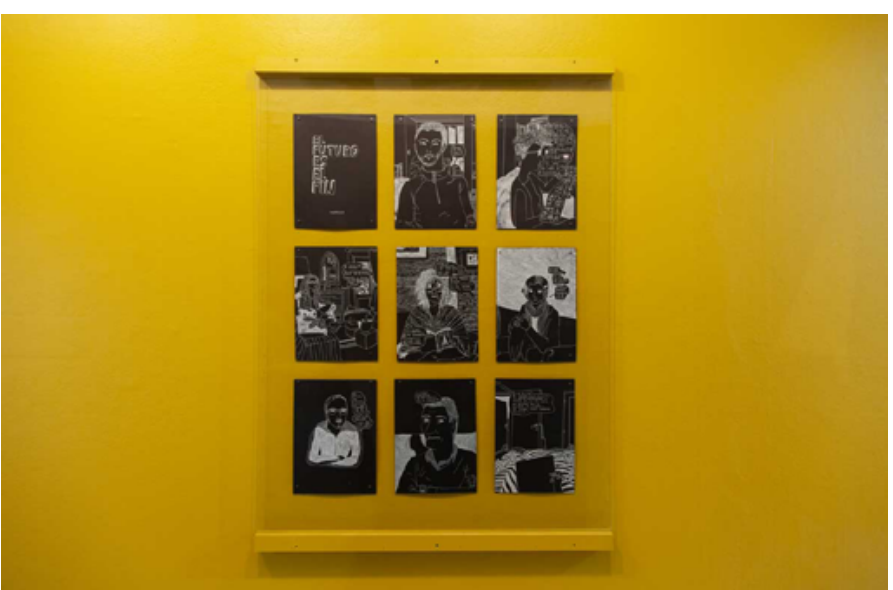

Figura 2. Originales de Powerpaola. Fuente: 45SNA - Colombia / MinCultura / Alcaldía de Bogotá, catálogo web, 2019.

las formas de articular las narraciones en los cómics. Ese fue el caso de la selección de algunos originales de la estadounidense Aidan Koch, que establecen un camino experimental y fuera de la narración convencional de la historieta. Koch, una destacada artista por sus numerosas exposiciones en museos y galerías, también presentó una proyección de las imágenes de su novela gráfica The Blonde Woman (2012) en uno de los muros de la sala. Algo parecido ocurrió con la incorporación de un dibujo en gran formato de Camilo Restrepo. Sobre ese trabajo el curador afirmó que «en el contexto del arte no se pensaría como cómic, pero plantea relaciones muy interesantes tanto por su "arquitectura paisajística" como por el uso de los íconos/caricaturas» (Martín, entrevista).

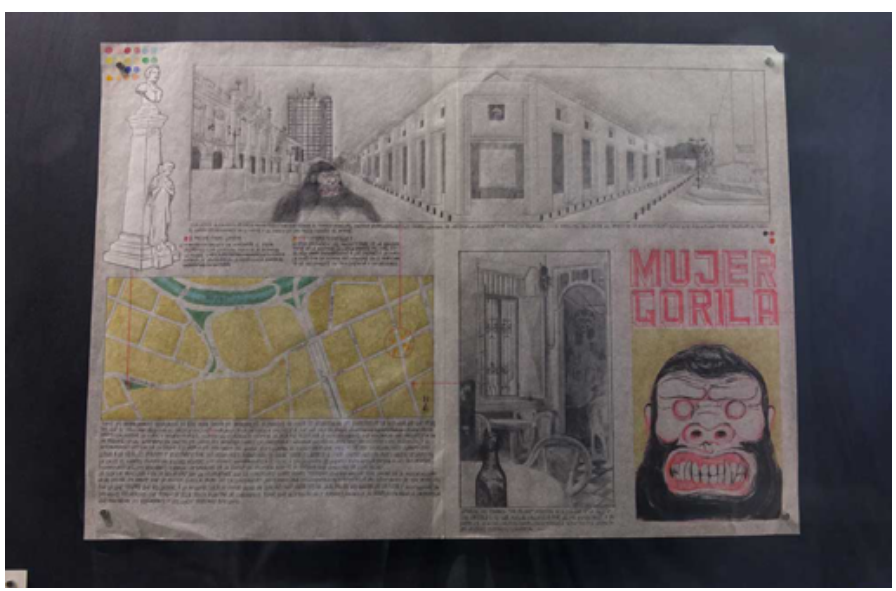

Figura 3. Mujer gorila de Luto. Fuente: 45SNA - Colombia / MinCultura / Alcaldía de Bogotá, catálogo web, 2019. 
Otra selección llamativa fue una serie de tres esculturas de la artista plástica Carmenza Banguera que aborda el racismo por medio de un helado de chocolate que se derrite. Para el curador se trataba de «un cómic en versión escultura». Por último, del artista plástico y profesor de arte Lucas Ospina ${ }^{8}$ se incluyó una escultura en bronce y algunos dibujos realizados a partir de una especie de reto, en el que el dibujante proponía dibujos que acotaban o dialogaban con las obras presentes en esta muestra.

El original fue la pieza museística más

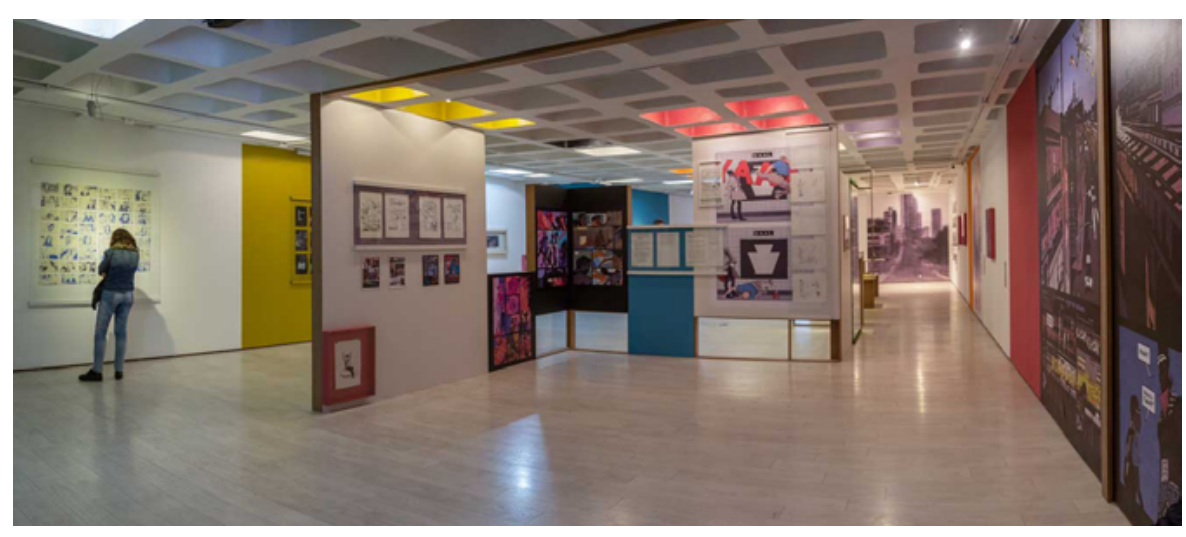

Figura 4. Panorámica de Arquitecturas narrativas. Fuente: 45SNA - Colombia / MinCultura / Alcaldía de Bogotá, catálogo web, 2019. apetecida para la muestra (figura 4), tal vez por ser el objeto que mejor refleja la intención artística del proceso creativo y que, al no ser una reproducción, conserva la singularidad de formas de arte más tradicionales, como la pintura (Méon, 2015, 448-450). Además, el diálogo entre cómic y arquitectura refleja un modelo de exposición que reivindica el aspecto visual y formal de la historieta. Se privilegió la apreciación visual sobre la dimensión narrativa del cómic. Una alternativa al original fueron las reproducciones a gran escala que enfatizan en el talento del creador (Quirion, 24) y, para el curador, evidencian la relación entre la arquitectura de la ciudad y la arquitectura de la página.

La forma de desplegar los objetos en el espacio se concibió como un gran cómic (Martín, 188). Para ello, se aprovechó la cuadrícula del techo de la sala que evoca una retícula de viñetas, incorporando luces de colores en algunos de los escaques, con el objetivo de generar un recorrido arquitectónico para el visitante. Al momento de la instalación se dejaron vacíos entre los paneles modulares, como ventanas que comunican las piezas artísticas. En una entrevista personal, el curador afirmó que descomponer las piezas en los muros y pensar en la ubicación de cada una dentro de un diseño global, era acudir a la idea originaria de la arquitectura narrativa. Hay que resaltar el juego de escalas por los diferentes

\footnotetext{
Este artista fue comisionado, junto con la dibujante Powerpaola, para realizar un mural en una de las paredes exteriores del Centro Colombo Americano, como parte de esta curaduría. Dicho mural fue censurado por incluir entre sus imágenes una ilustración del actual presidente de Colombia, Iván Duque, caracterizado como una marioneta controlada por el expresidente Álvaro Uribe Vélez, quien a su vez era manipulado por el titiritero Donald Trump. Estas imágenes fueron borradas del mural, lo que desencadenó protestas de la comunidad artística y del público en general, aunque legitimó la consigna del salón, mostrando que aún no es fácil visibilizar artísticamente «el revés», pues «la trama» oficial luchará por imponerse.
}

tamaños de imágenes que se expusieron, pues se incluyeron impresiones en gran formato de Gusanillo, Luto y Wimberly, más la proyección de dibujos de Koch.

El gran mérito de esta curaduría —además de asumir el cómic como un medio y una práctica legítima dentro del campo artístico, al punto de abrirle una exposición exclusiva dentro de un salón nacional- es su interés por reflexionar en torno a las diversas formas de concebir y gestionar el espacio, a través de una serie de paralelos o metáforas entre la espacialidad de los cómics (la gestión del espacio bidimensional de la página), y otras formas espaciales de la arquitectura, la ciudad, o el museo: las convenciones de la representación del volumen y la tridimensionalidad tanto en el diseño arquitectónico como en el dibujo de la historieta; la retícula urbana, el plano o mapa de la ciudad, y la retícula de las viñetas; y la posibilidad de hacer recorridos interpretativos y procesos de lectura de las historietas en la disposición vertical de los muros como superficie de exposición.

No obstante, el adjetivo «narrativas» que aparece en el título de esta curaduría puede generar expectativas en los espectadores que no siempre se cumplen. La dimensión narrativa supone una continuidad, una secuencia o relato que enlace las obras, además del principio conceptual de la espacialidad, que en este caso cede su lugar a la fragmentación. Una de las estrategias curatoriales para integrar las obras en medio de la discontinuidad de sus temáticas fue la obra de Lucas Ospina. En palabras del propio artista (2019):

Los dibujos que estoy mostrando en la exposición, en la sala del Colombo Americano, pueden entenderse como «pie de citas» a las obras de los otros artistas (...). Lo que hicieron fue 


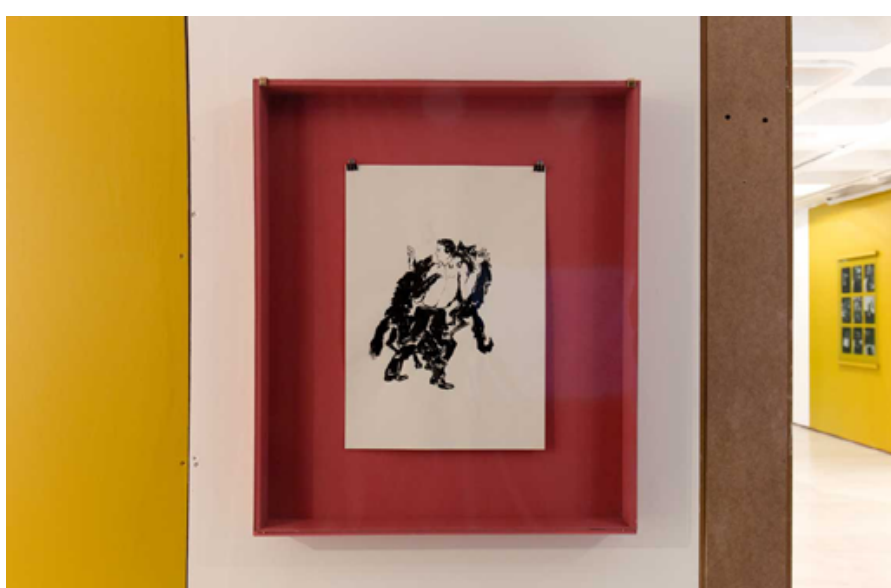

Figura 5. Dibujo de Lucas Ospina. Fuente: 45SNA - Colombia / MinCultura / Alcaldía de Bogotá, catálogo web, 2019.

enviarme muestras del trabajo que iban a exponer los otros artistas, y yo intenté hacer los dibujos que respondieran a esos dibujos. [Mis dibujos] Son como una especie de comodines que le sirven también a la curaduría para poder hacer transición entre una obra y otra o para tener un elemento constante que ayuda para que el público pase de una obra a la otra pero que tenga un elemento con el que se sienta más familiar?

Este objetivo integrador se logra parcialmente pues, aunque el marco rojo y la posición periférica de los dibujos de Ospina efectivamente permite leerlos como un paratexto visual a las obras de los otros artistas, sus motivos gráficos parecen aleatorios frente a los de las obras comentadas. Además, aunque la intención era que lucieran como viñetas, su marco tradicional los hace disruptivos en relación con las ampliaciones de cómics o con los dibujos originales de otras historietas (figura 5).

No obstante, el adjetivo «narrativas» del título de esta exposición puede tener un sentido más amplio que el que se le da en la definición tradicional de historieta como «narración gráfica», y más cercano a la manera como se usa en los estudios culturales y la teoría estética contemporánea, en donde se puede entender narrativa como un discurso social o cultural que organiza la experiencia desde una perspectiva específica. Un ejemplo de este sentido lo ofrece la obra Mi negrito, de Carmenza Banguera (figura 6), que denuncia una narrativa racista en los materiales de dibujo. Martín (2019) describe la obra así:

9 El testimonio completo de Lucas Ospina se puede ver en el siguiente enlace: https://www.youtube.com/watch?v=A1GQZmVxAQ0

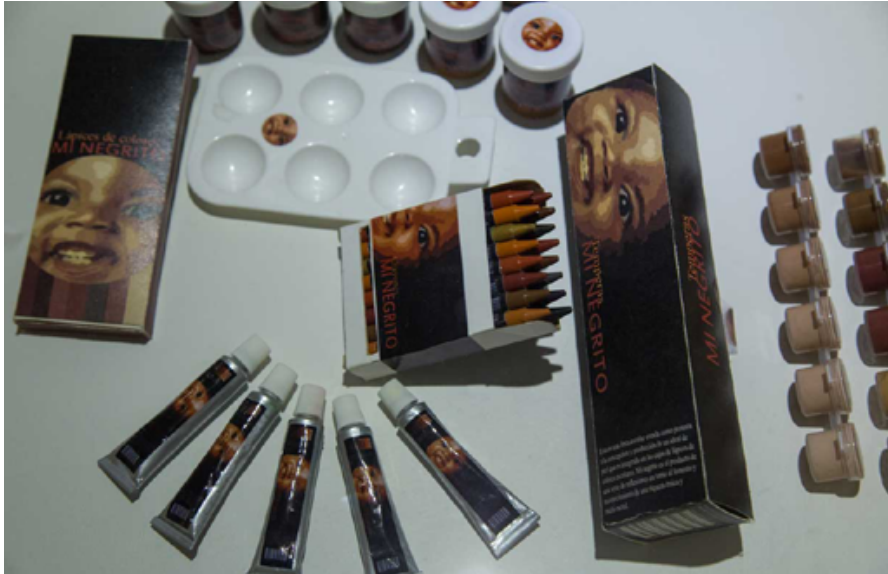

Figura 6. Mi negrito de Carmenza Banguera. Fuente: 45SNA - Colombia / MinCultura / Alcaldía de Bogotá, catálogo web, 2019.

En esta pieza, Banguera nos presenta un set de colores: acrílicos, acuarelas y crayones con los diversos tonos de los colores de la piel de los afrodescendientes. Esta "herramienta didáctica" choca de frente con esos lápices "color piel" con los que muchos crecimos. El humor es fundamental en el trabajo de esta artista que evita todos esos clichés que reducen los cuestionamientos al racismo estructural a una única línea identitaria. (23)

La otra parte de la obra de Banguera consta de tres esculturas que continúan este develamiento de narrativas racistas: «Su serie de tres esculturas, en las que un personaje dibujado sobre un helado de chocolate se derrite, consigna sintéticamente la crueldad y el drama de enfrentar la mirada racista, aparentemente ingenua, con la experiencia de quien es así mirado» (23). Estas esculturas ofrecen, además, una continuidad que se ajusta a la idea de narración gráfica tradicional: son tres imágenes yuxtapuestas en secuencia deliberada (figura 7).

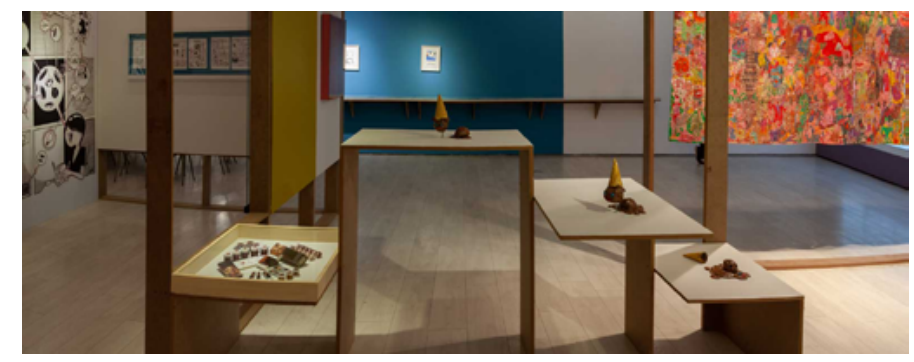

Figura 7. Serie de esculturas de Carmenza Banguera. Fuente: 45SNA - Colombia / MinCultura / Alcaldía de Bogotá, catálogo web, 2019. 
A través de estas estrategias, la curaduría de Arquitecturas narrativas abre, de manera más generosa, el espacio artístico a artistas provenientes directamente del mundo del cómic, y sus imágenes a las superficies de la escenografía curatorial, que les habían sido esquivas durante tanto tiempo.

\section{El cómic como publicación artística: Llamitas al viento}

Esta curaduría corresponde al programa de publicaciones del 45SNA, y estuvo a cargo de Manuel Kalmanovitz, escritor, artista y académico con amplia experiencia en el mundo editorial independiente y en la reflexión artística ${ }^{10}$. Esta sección de publicaciones estuvo dividida en tres categorías: Cuadernos de fotografía, Cuadernos de cómic y dibujo y Libros del revés. Es necesario aclarar que, en este caso, la curaduría de publicaciones no se refiere al material informativo o documental que acompaña cualquier exposición, sino de un espacio curatorial consagrado a publicaciones artísticas, entendidas como obras o procesos de arte que toman el formato impreso como su medio de expresión ${ }^{11}$.

De ahí que, por un lado, el cómic encuentre en esta curaduría el lugar que le es connatural en tanto medio impreso, pero, por otro lado, que vea confrontadas sus formas editoriales, estéticas y narrativas con otras publicaciones de la esfera del arte como los Cuadernos de fotografía, un medio central en las prácticas artísticas contemporáneas, o los Libros del revés, correspondiente a proyectos donde la publicación es parte de un conjunto más amplio de procesos artísticos, como se puede colegir del texto curatorial, según el cual esta categoría «es la más abierta y en la que confluyen toda clase de aproximaciones, desde textos hasta dibujos y grabados, pero todos los proyectos coinciden en indagar acerca de lo que consideramos real y las pistas camufladas por ahí que apuntan en otras direcciones» (Kalmanovitz, 2019, 134-135).

Otro elemento que confronta al cómic en esta curaduría es el hecho de que la categoría que le corresponde no se circunscribe solo a los cómics, pues al separarlo en su título del dibujo (aunque sea con la conjunción «y»), se abre la puerta

10 Su trabajo editorial se ha centrado en la revista Matera que circula desde 2009 en Colombia. Allí reúne ensayos, cuentos, fotografías, poemas, dibujos, fotonovelas y otras creaciones artísticas. Véase la página de Facebook de esta publicación: https://www.facebook.com/La-Revista-Matera-386953098118314/

Sobre la edición como práctica artística véase: Gilbert, Annette, Ed. Publishing as Artist Practice. Berlín: Sternberg Press, 2016.

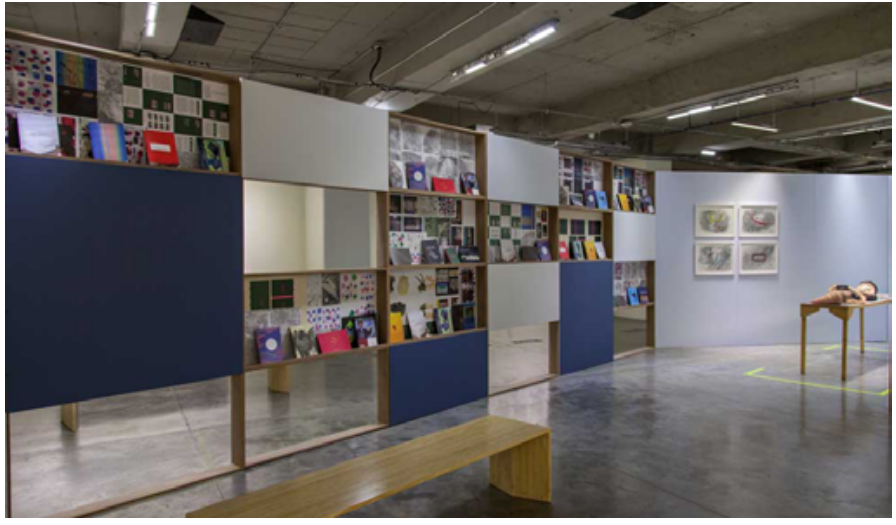

Figura 8. Panorámica de Llamitas al viento. Fuente: 45SNA - Colombia / MinCultura / Alcaldía de Bogotá, catálogo web, 2019.

a un conjunto heterogéneo de proyectos gráficos, algunos de los cuales se alejan radicalmente de las convenciones de la narración gráfica. Así mismo, el hecho de que esta curaduría reuniera a proyectos editoriales que resultaron seleccionados a través de convocatorias públicas ${ }^{12}$, junto con obras o publicaciones de artistas invitados por el curador por sus trayectorias previas, le añade otro grado de diversidad. La diferencia fundamental entre estos dos procesos de selección es que, mientras la participación de los ganadores de convocatorias se restringía a la muestra y distribución de sus publicaciones, algunos de los artistas invitados formaron parte además de una exposición en el museo ${ }^{13}$, con obras de diversa índole colgadas en los muros o dispuestas a manera de instalaciones, o participaron también en otras de las exposiciones del 45SNA.

De acuerdo con esto, la curaduría Llamitas al viento incluye dos tipos de artefactos u objetos expositivos: publicaciones (los denominados cuadernos) y obras de arte de diversa índole, que van desde impresiones, dibujos y grabados originales, hasta esculturas, instalaciones y performances (figura 8). Es el caso de la obra de Mónica Naranjo Uribe, autora del cuaderno Caminar entre los otros — quien además participó en $A r$ quitecturas narrativas con la obra $W$ here here and there meet- una

12 La convocatoria correspondiente a la ciudad de Bogotá se ofreció como una Beca para proyectos editoriales independientes - 45 Salón Nacional de Artistas, que incluía las tres categorías que conforman esta curaduría. Los seleccionados a través de este proceso en la categoría de Cuaderno de cómic y dibujo fueron Mónica Naranjo Uribe (Caminar entre los otros), Juan Alberto y Camilo Conde (Mostrillo), y Andrés Frix Bustamante (Chungo Zine). En Medellín se abrió la Convocatoria de Estímulos para el Artey la Cultura, cuyos ganadores fueron las obras Zona de Confort, de Joni B, y Costillas de cómic con cerveza, de Truchafrita.

La exposición de los Cuadernos de cómic y dibujo tuvo lugar en el espacio El Parqueadero, una sala del Museo Miguel Urrutia del Banco de la República, que antes fue un estacionamiento de vehículos y ahora un sitio para talleres y exposiciones. 


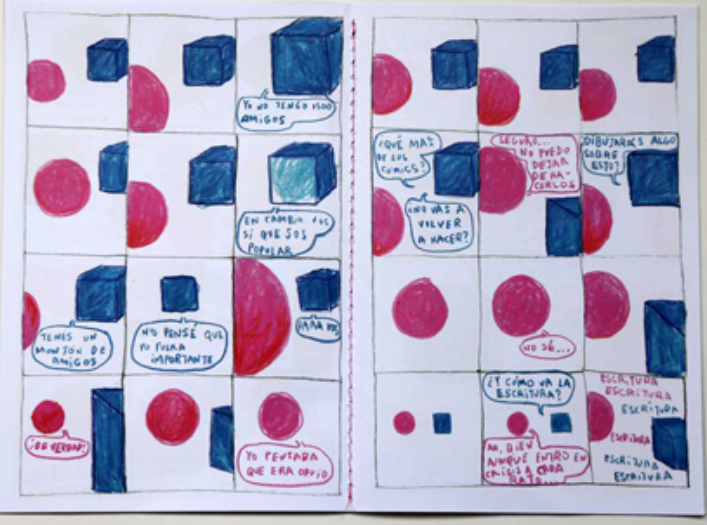

Figura 9. Platónico imperfecto de Mariana Gil Ríos. Fuente: 45SNA - Colombia / MinCultura / Alcaldía de Bogotá, catálogo web, 2019.

combinación de fotografías y dibujos derivadas de recorridos por paisajes y ciudades de diversos países; o de Mariana Gil Ríos, artista visual y dibujante, quien también formó parte de la curaduría Instancias con un performance titulado Secernere - Acto de Habla, además de conformar parte de Llamitas al viento con su publicación Platónico imperfecto, un cómic abstracto cuyos personajes son figuras geométricas que sostienen conversaciones cotidianas (figura 9). Así mismo, Mariana Gil expone una serie de objetos escultóricos en la curaduría de Kalmanovitz, que acompañan sus ilustraciones, algunas de las cuales están dispuestas en los muros.

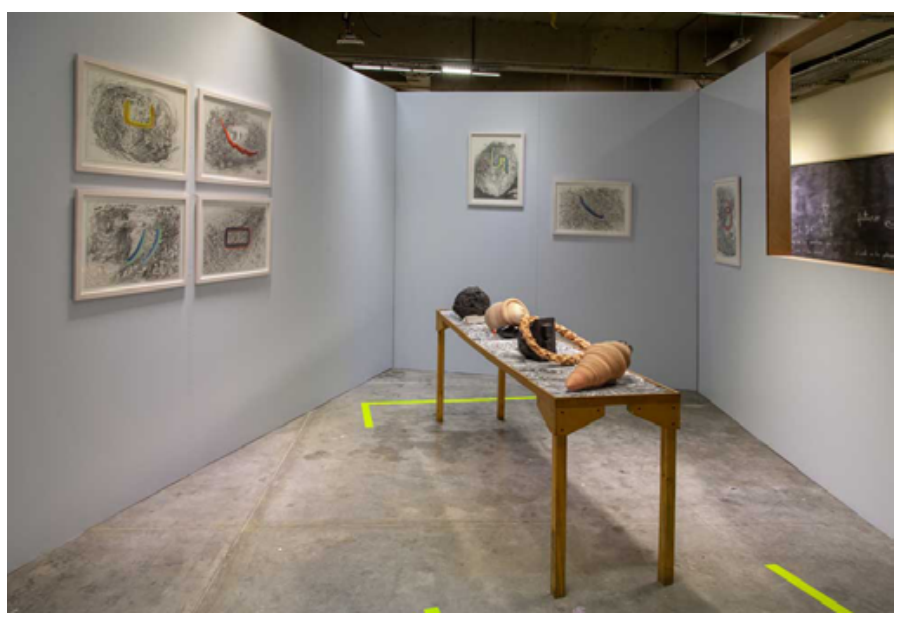

Figura 10. Obra de Natalia Castañeda. Fuente: 45SNA - Colombia / MinCultura / Alcaldía de Bogotá, catálogo web, 2019.
Un caso similar es el del «fanzinero» e historietista M. A. Noreña ${ }^{14}$ y su cuaderno No ver/volver a ver, algunas de cuyas páginas originales están expuestas en estanterías dentro del espacio del museo. La obra de Noreña también colinda con la abstracción, y Kalmanovitz (2019) la describe así en el texto curatorial: «En las imágenes de su publicación se propuso un juego modular en el que cada página es un universo cerrado que cobra otros sentidos dependiendo de lo que viene antes y después» (199). Dado este carácter modular, el orden de exposición de estas imágenes en la sala era cambiado periódicamente.

También forma parte de este grupo el trabajo de Natalia Castañeda, cuyos dibujos originales están expuestos en los muros de la sala, y otros están dispuestos en una mesa, formando la base de objetos cerámicos que extienden sus trazos abstractos hacia la tridimensionalidad (figura 10). Estos mismos dibujos, de texturas gestuales fuertemente expresivas, aparecen en su publicación, Una semana de bondad o Euforias olvidadas, formando texturas que a veces funcionan en clave abstracta, o en otras ocasiones se interpretan como follajes explosivos que rodean a personajes o a parajes urbanos.

La obra del dibujante Kevin Mancera también está enmarcada y expuesta en el museo en dos paneles contiguos, además de la presentación de su cuaderno Entre ramas me muevo (o Entre las ramas ando). Se trata de ilustraciones que siguen una continuidad gráfica más que narrativa, pero que parecen habitar un mismo mundo, selvático y oscuro. En una línea similar, fuera del cuaderno Badlands, el artista caleño Manuel Hernández participa en Llamitas al viento con una serie de banderas de tela bordadas con colores vivos, que «podrían ser emblemas de equipos de fútbol, de barrios periféricos, de organizaciones obreras o de universidades donde se enseñan artes mágicas al lado de ingenierías» (Kalmanovitz, 130).

El carácter inefable o la tendencia a la abstracción de las obras antes mencionadas se entiende mejor si se recuerda la idea que orienta la curaduría de Llamitas al viento, cuyo título proviene de un verso del poema Futuro, de Porfirio Barba Jacob, que evoca la inestabilidad y fragilidad de una llama, pero a la vez su fuerza iluminadora ${ }^{15}$. De ahí también que

\footnotetext{
14 Noreña es un dibujante de historietas de vieja data que se ha movido en la escena del cómic colombiano durante casi tres décadas. Su última publicación es jPuedo sentarme aquí? (2021), editada por Mapache Cómics. Véase: https://manoregna.com/ 15 Dice la tercera estrofa del poema Futuro: «De simas no sondadas subía a las estrellas; / un gran dolor incógnito vibraba por su acento; / fue sabio en sus abismos, - $-\mathrm{y}$ humilde, humilde, humilde, / porque no es nada una llamita al viento...» (Barba Jacob, 42).
} 
su categorización como cómics no siempre sea clara, o que se inscriban dentro de las formas más experimentales de este medio: más cercanos a la poesía gráfica que a la narración gráfica, o que sean abiertamente cómics abstractos ${ }^{16}$. Y en una línea similar, la mayoría de estas publicaciones no se pueden entender como objetos editoriales autónomos, sino que forman parte de procesos, acciones o gestos performativos que orientan su sentido.

Pero Llamitas al viento incluye también otro grupo de obras que se inscriben de manera más tradicional en el campo de los cómics. Se trata, precisamente, de trabajos cuyo eje central (e incluso único) es la publicación impresa, y que involucran una dimensión narrativa más nítida. Una de estas obras es Zona de Confort, de Joni $\mathrm{B}^{17}$, un narrador gráfico reconocido a nivel nacional e internacional, cuya obra Maldito planeta azul (2012) fue publicada en España por la Editorial Periférica, y que en este caso fue premiado en la convocatoria de Medellín. Se trata de un relato gráfico que, en la línea de cómics anteriores de este dibujante como Parque del Poblado (2011, Editorial Robot), captura momentos cotidianos de un grupo de amigos en una noche de copas, sin más pretensión que mostrar las tensiones y los momentos agudos de la conversación entre viejos conocidos.

Este tono cotidiano también está presente en la obra Costillas de cómic con cerveza de otro autor proveniente de Medellín, Álvaro Vélez (Truchafrita), un dibujante de cómics con una trayectoria extensa y reconocida ${ }^{18}$, y que en esta historieta retoma los personajes de su universo narrativo, construidos en obras previas como Cuadernos Gran Jefe. Truchafrita es además su alter ego narrativo y los diálogos que sostiene con sus amigos forman parte de «un mundo que se delinea con un dibujo cuidadoso y sobrio y en el que los personajes, algunos con rasgos humanos y otros de animales, departen pacíficamente haciéndose preguntas sobre el sentido de la existencia (...)» (Kalmanovitz, 133).

Por su parte, el cómic Mostrillo, de los hermanos Juan Alberto y Camilo Conde ${ }^{19}$, se inscribe en otro de los géneros

\footnotetext{
A propósito de la relación entre cómic y abstracción, véase el catálogo de la exposición Comic Abstraction: Image-Breaking, Image-Making, realizada en el MoMA en 2007.

Véase la entrada sobre este dibujante colombiano en Tebeosfera: https://www. tebeosfera.com/autores/benjumea_joni.html

18 Truchafrita es una referencia ineludible en la historieta colombiana. Autor de las quince ediciones de Cuadernos Gran Jefe y editor de la reconocida gacetilla de cómics Robot desde 2003. Sus dos últimas publicaciones son Follaje (2019, Tragaluz Editores) y Dias de cuarentena (2020, Editorial Robot).

Juan Alberto es profesor e investigador de la Universidad de Bogotá Jorge Tadeo Lozano. Ha escrito varios artículos y reseñas sobre cómics. Por su parte, Camilo es
}

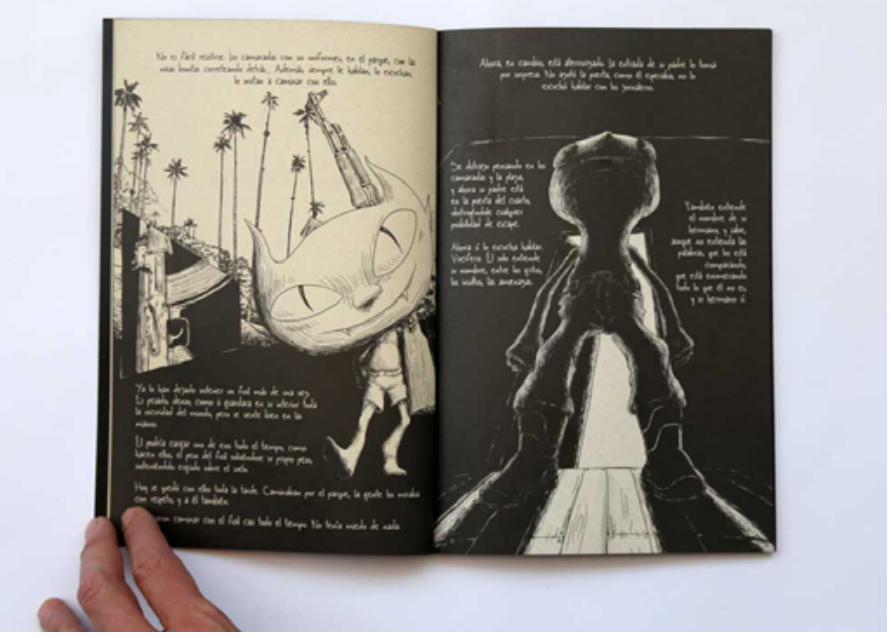

Figura 11. Mostrillo de Juan Alberto y Camilo Conde. Fuente: 45SNA - Colombia / MinCultura / Alcaldía de Bogotá, catálogo web, 2019.

realistas de la narración gráfica: el cómic testimonial, pues constituye el primer episodio de una novela gráfica consagrada a narrar la vida de un personaje real cuyas circunstancias personales lo hicieron formar parte de los diversos grupos violentos que han protagonizado el conflicto armado que se ha vivido en Colombia durante décadas: la guerrilla, el paramilitarismo y la delincuencia común, asociada al narcotráfico y el sicariato. En esta primera entrega, los hermanos Conde relatan su infancia, hasta justo antes de ser reclutado por un grupo guerrillero (figura 11).

Finalmente, hay que mencionar el cuaderno Chungo Zine, del artista plástico Andrés Frix Bustamante ${ }^{20}$, que se encuentra en un punto intermedio entre estas dos líneas de publicaciones pues, por un lado, comparte con los cuadernos de artista su distanciamiento de la narratividad y su búsqueda plástica a través de los formatos impresos, y por otro lado forma parte del formato del fanzine, tan cercano a los cómics en su forma más underground, involucrando también una gráfica que evoca este tipo de cómics.

un dibujante, realizador audiovisual y director del Estudio Panca: http://estudiopanca.co/panca/index.html. Mostrillo es el primer cómic de ambos.

20 Andrés Bustamante Sandoval es un artista bogotano con amplia trayectoria en el mundo del fanzine y los cómics, expresiones que aborda en intersección con prácticas artísticas. También es investigador y curador. Dirige La Ramona proyectos / Espacio 101, un lugar de exposiciones y proyectos editoriales ubicado en Bogotá. Véase: https://andresfrix.wixsite.com/andresfrix/obras 
Así, Llamitas al viento nos confronta con otro tipo de exposición, que se aleja de las tipologías construidas por autores como Méon (2019) o Munson (2020), dado que asume el cómic como una estrategia más dentro del conjunto de prácticas del arte contemporáneo, y no como un medio independiente que debe ser legitimado a través de su incorporación en el «cubo blanco» del museo de arte. En ese sentido está en línea con ese tipo de cómics que responden con un sî a la pregunta formulada por Thierry Groensteen en su obra Comics and Narration: ¿es el cómic una rama del arte contemporáneo?

Para este autor, en cambio, la respuesta parece ser negativa, pues describe con desconfianza los proyectos gráficos que se alejan de la narratividad o de otras convenciones de este medio, adentrándose en los terrenos de las prácticas artísticas contemporáneas. Groensteen (2013), quien se basa en el sociólogo del arte Howard S. Becker, considera que el cómic y el arte contemporáneo pertenecen a «mundos artísticos» (Art Worlds) distintos, aunque no descarta que sea legítimo para algunos artistas del cómic «emanciparse de la narrativa», pero los ubica «en la periferia del campo de los cómics» (171-176). Las curadurías del 45SNA que involucraron el cómic demuestran que esta idea es relativa, pues en contextos como el colombiano, donde el cómic no se ha consolidado completamente como un campo, en el sentido de Bourdieu o Boltanski (1975), o en un mundo, en el sentido de Becker, las reglas parecen ser más flexibles.

A diferencia de otros países de Latinoamérica, como México, Cuba o Argentina, Colombia carece de una tradición de producción de cómic, lo que ha provocado un ecosistema débil y precario. Sin embargo, en los últimos años se observa la emergencia de autores y editoriales que potencian el panorama, sin llegar a consolidar una industria. Y es, precisamente, esa precariedad la que ha dado lugar a una mayor flexibilización, como la apertura del cómic con otras prácticas artísticas contemporáneas.

\section{Los cómics activistas: Contrainformación}

Una mirada crítica hacia las narrativas de la historia fue la propuesta curatorial del Equipo TRansHisTor(ia), conformado por María Sol Barón y Camilo Ordoñez, en Contrainformación. El dúo ha realizado curadurías y publicaciones que involucran la cultura visual, la historia del arte y la imaginación política. Su exposición fue una de la más grandes del 45SNA por incluir un gran número de trabajos artísticos. En palabras del curador Ordoñez, al periódico El Espectador, se trataba de «reunir un conjunto de prácticas artísticas y culturales donde se logra reconocer la coexistencia de diferentes relatos económicos, políticos, culturales que son capaces de confrontar la historia preestablecida» (Fernández, 2019). Para ello, la curaduría se articuló en tres espacios, uno de ellos fue la Galería Santa Fe que abarcó una selección de prácticas artísticas contemporáneas, incluida la muestra de algunos cómics: Felicita Campos, la mujer campesina en la lucha por la tierra y El Boche, campesino rebelde del Sinú del monteriano Ulianov Chalarka, La increíble y triste historia de la Reforma Agraria y su Incora desalmado del australiano Joe Broderick y Auge del vaupense Tomasito Neira.

La selección de esas historietas proviene del trabajo investigativo de varios años de los curadores. Quizá la obra de Chalarka sea una de las más llamativas por su origen. A principios de la década de los setenta se introdujo en el departamento de Córdoba una metodología de investigación, conocida como Investigación Acción Participativa (IAP), que integraba activismo, conocimiento popular y académico, en pro de una ciencia social comprometida con los movimientos y las luchas sociales. El método fue incorporado por el sociólogo Orlando Fals Borda y otros científicos sociales que se habían organizado en Bogotá como Fundación La Rosca. Según Negrete (2008), la llegada de La Rosca a la Costa Atlántica coincidió con el auge del movimiento campesino a través de la Asociación Nacional de Usuarios Campesinos (ANUC) y la creación de la Fundación del Caribe, un colectivo conformado por locales de Montería (Córdoba). Esa triada de organizaciones fue la base para aplicar la IAP.

Las primeras experiencias investigativas involucraron al campesinado de la parte suroccidental de la región Caribe «para recuperar la historia de la organización campesina y popular, fortalecer la organización y desarrollar procesos de educación populan» (García y Ojeda, 139). La agenda investigativa se proponía, por un lado, «identificar aquellas instituciones que históricamente jugaban papeles importantes en las luchas campesinas, con el propósito de readecuarlas dentro del contexto de trabajo de la ANUC» (Rappaport, 137) y, por el otro, devolver a la comunidad los resultados de la investigación por medio de diferentes actividades y materiales. Es así como el cómic fue uno de esos materiales para dar a 


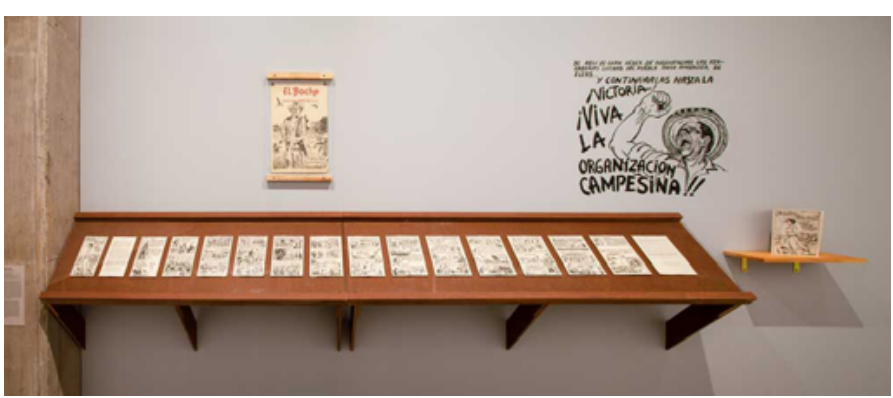

Figura 12. Adaptación museística de Felicita Campos y El Boche. Fuente: 45SNA - Colombia / MinCultura / Alcaldía de Bogotá, catálogo web, 2019.

conocer en las bases del movimiento campesino, «que en su mayoría no sabía leer ni escribir» (Rappaport y Negrete, 38), los relatos de sus luchas.

Entre 1972 y 1974 se publicaron cuatro historietas, cada una tomó alrededor de seis meses de trabajo y su extensión oscilaba entre quince a veinte páginas (Rappaport, 141). Aunque Ulianov Chalarka, artista autodidacta que se crio en Montería, fue el encargado del dibujo, la elaboración de los cómics fue un proceso muy participativo. Chalarka asistía a las reuniones con las comunidades campesinas para tomar «apuntes dibujados»y, al final de la sesión, el público le ofrecía sus análisis para mejorar la historia. Luego, los miembros de la Fundación del Caribe y dirigentes campesinos se encargaban «de la maquetación, en la que se unían los bocetos en paneles y se agregaban globos con diálogo y cartelas con narraciones verbales» (Rappaport, 142). Por último, el borrador pasaba a aprobación final para su impresión y circulación en forma de folletos (Rappaport y Negrete, 2015; Rappaport, 2018). Como puede verse cada historieta fue producto de un trabajo reflexivo y colectivo.

De los cuatro cómics ${ }^{21}$, los curadores seleccionaron el trabajo sobre Felicita Campos, la mijer campesina en la lucha por la tierra y El Boche, campesino rebelde del Sinú porque se concentraban en personajes concretos y «eran las piezas que más fuertemente dialogaban con los postulados planteados en Contrainformación» (Barón y Ordoñez, entrevista por correo electrónico, 20 de enero de 2021). Además, desde el 2012 se habían acercado al folleto de El Boche por una curaduría y, más adelante, a la figura de Felicita Campos (figura 12). Ambos cómics son semejantes en muchos aspectos de su

\footnotetext{
21 Las historietas fueron compiladas por la Fundación del Sinú, en 1985, bajo el título Historia gráfica de la lucha por la tierra en la Costa Atlántica. Luego, el Centro Nacional de Memoria Histórica reimprimió esa publicación. Y en 2019 se publicó una edición facsimilar por La Silueta Ediciones y el proyecto Piedra, Tijera, Papel.
}

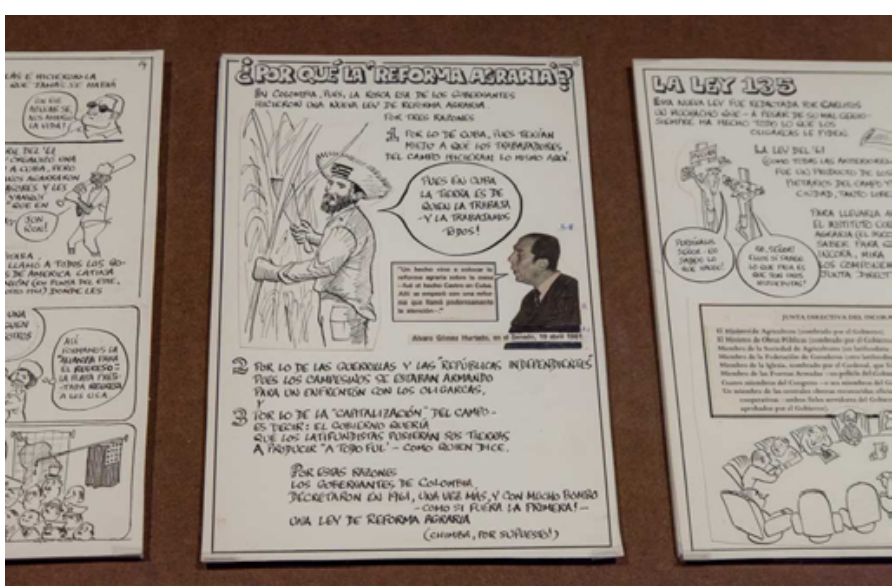

Figura 13. Original de La increíble y triste historia de la Reforma Agraria y su Incora desalmado. Fuente: 45SNA - Colombia / MinCultura / Alcaldía de Bogotá, catálogo web, 2019.

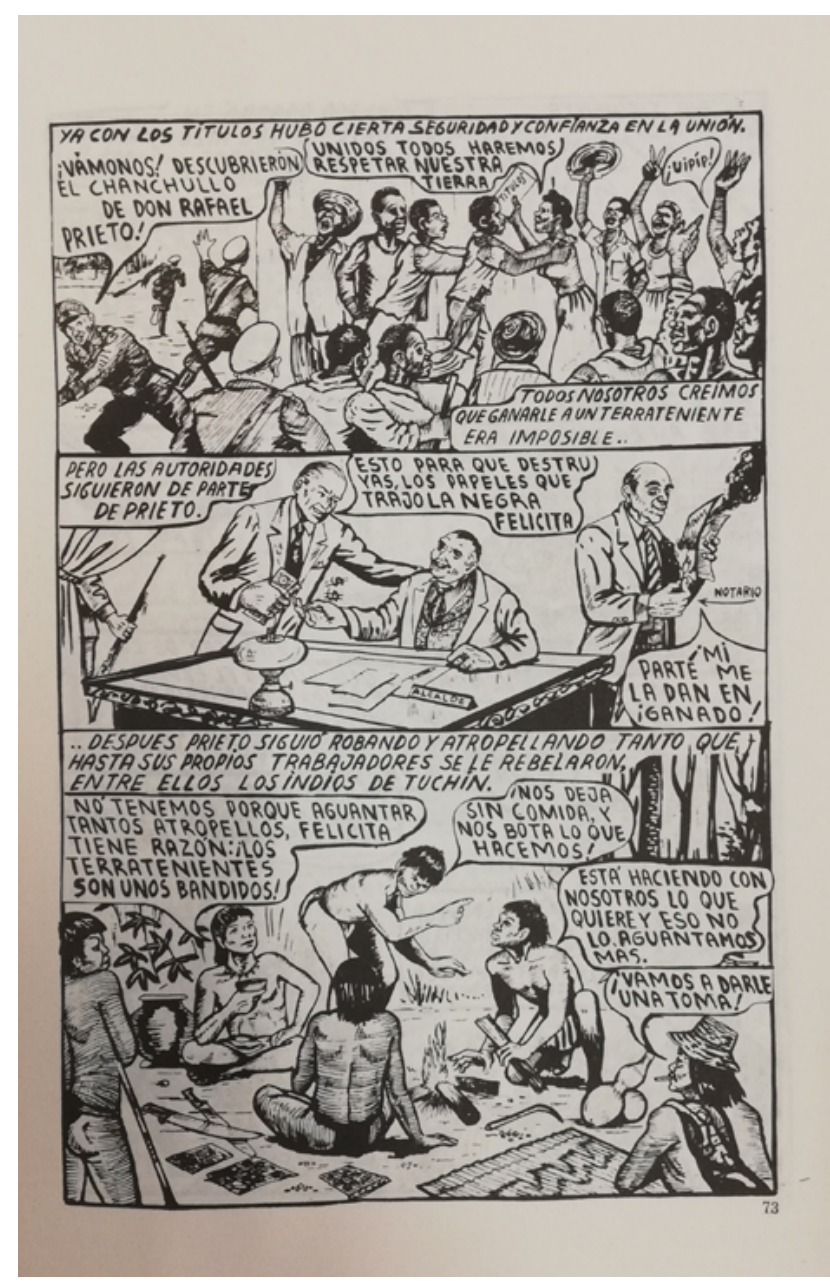

Figura 14. Página interior de Felicita Campos. Fuente: Chalarka $(1985,73)$. 
contenido: visibilizan la represión en contra de líderes regionales y reivindican las luchas por la tierra.

La obra de Chalarka sostiene una fuerte relación temática con La increíble y triste historia de la Reforma Agraria y su Incora desalmado de Joe Broderick. Ambos trabajos son dos caras de una misma moneda por centrarse en los problemas agrarios. Incluso, el origen de la historieta de Broderick se relaciona también con el auge de la ANUC, a principios de la década de los setenta, ya que fue este movimiento campesino el que lo comisionó para elaborarla en 1974. Además, circuló en forma de folleto o cartilla, soporte muy apetecido para los procesos de educación popular, y tuvo el mismo objetivo de estimular al campesinado a conocer su pasado y colaborar en la lucha por la tierra. Eso sí, la cartilla de Broderick no tuvo el profundo proceso participativo de los folletos de Chalarka. Fuera de ello, su dibujo y composición de páginas se distancian del trabajo de Ulianov. El trazo caricaturesco y el diseño libre de Broderick (figura 13) contrastan con el trazo realista y la retícula de Chalarka (figura 14).

Por otra parte, la historieta de Broderick sintoniza con el trabajo del mexicano Eduardo del Río, conocido como Rius y que realizó los cuadernillos de Los supermachos y Los agachados, y es «un pionero y modelo para muchos productores de cómic político en América Latina» (Barón et al., 17). Aunque Joe sea de origen australiano, su vasta producción gráfica se desarrolló en Colombia y con relación a los temas políticos del país. La selección de este cómic en Contrainformación ya tenía un precedente en el trabajo investigativo de los curadores por un libro y exposición del 2018 sobre sus caricaturas e historietas ${ }^{22}$.

A estas obras se sumó un cómic, en formato de fanzine, sobre la explotación del caucho en el Amazonas de Tomasito Neira. A diferencia de las anteriores historietas, su germen no se localiza en los movimientos sociales ya que fue comisionada para la muestra. La pesquisa de Neira, artista del Vaupés, fue fruto de una revisión por parte de los curadores a lo que sucedió en los Salones Regionales del 2018. En este caso la contrainformación se lee en dos sentidos: la incorporación de un relato contrahegemónico y la inclusión de un joven historietista alejado de los circuitos del cómic nacional.

22 El equipo TRansHisTor(ia), en compañía de la artista plástica Gabriela Pinilla, publicó gracias a una beca de proyectos editoriales de Idartes el libro De la vía armada a la vía láctea. Monos e historietas de Joe Broderick que documenta el trabajo gráfico del australiano e incluye tres facsimilares de sus cartillas. Fuera del lanzamiento del libro, hubo una muestra de sus originales en la Sala de Exposiciones de la Facultad de Artes ASAB de la Universidad Distrital Francisco José de Caldas (Bogotá).

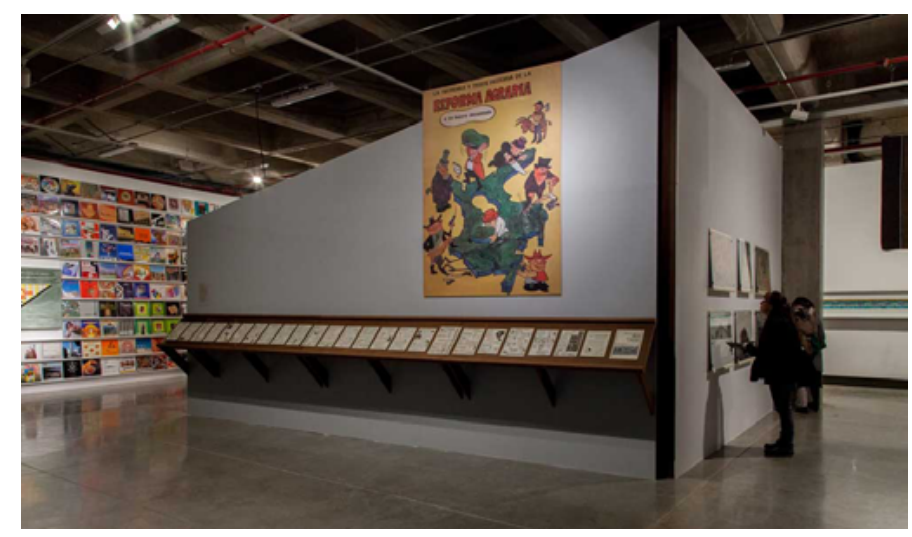

Figura 15. Adaptación museística de La increíble y triste historia de la Reforma Agraria y su Incora desalmado. Fuente: 45SNA - Colombia / MinCultura / Alcaldía de Bogotá, catálogo web, 2019.

Fuera de estas historietas, no queremos dejar de mencionar La Quintinada (1980), un «mapa parlante», ilustrado por Jorge Morales — como consecuencia de diálogos entre comunidades indígenas y los investigadores Víctor Daniel Bonilla y María Teresa Findji- por utilizar elementos del lenguaje del cómic, como la secuencialidad, que están en las raíces de lo que hoy llamamos historieta.

La forma de desplegar los cómics en el espacio fue homogénea: páginas en una vitrina lineal y cambio de superficie del papel al muro para exponer en gran formato la viñeta o la portada (figura 15). Los objetos de exposición se centraron en originales, reproducciones y publicaciones. Sólo en el caso de Broderick se mostraron dibujos originales. Esa forma de adaptar las piezas, a diferentes escalas, tenía como propósito «insinuar algunos aspectos materiales y formas de circulación de los cómics» (Barón y Ordoñez, entrevista). Además, el montaje evocó un modelo de exposición centrado en la técnica narrativa (Méon, 2015, 450-454) por la incorporación íntegra de los cómics en la vitrina y las publicaciones para la lectura del público. Aunque la muestra de los cómics no va más allá de exponer originales o reproducciones, sí guarda un equilibrio con el resto de las obras de la curaduría.

La incorporación de estos materiales en la muestra se acerca a los procesos del arte contemporáneo que Hal Foster (2001) denominó arte etnográfico, pero con la particularidad de que el trabajo de los artistas estuvo articulado con movimientos sociales y métodos participativos de investigación ${ }^{23}$. Así, el mayor acierto de esta curaduría fue expandir el análisis

Sobre el arte comprometido con procesos comunitarios véase: Crehan, Kate. Community Art: An Anthropological Perspective. New York: Berg, 2011. 
de esas obras del campo de las ciencias sociales al ámbito artístico y reivindicar su origen en las luchas populares, muchas de las cuales siguen vigentes. Valorar el poder de la estética de los cómics en la acción política fue la forma de mirar El revés de la trama y muestra otra línea en la que el cómic entra a formar parte de las prácticas artísticas contemporáneas.

\section{Conclusiones}

Las tres curadurías del 45SNA estudiadas en este artículo ofrecieron estrategias distintas en su aproximación al cómic y en su incorporación en el espacio del museo de arte contemporáneo, siguiendo una tendencia internacional cada vez más extendida en las dos últimas décadas: así, por ejemplo, en su edición número 12, en el 2007, la Documenta de Kassel (Alemania) incluyó obras de cómic como las de Kerry James Marshall24, Nedko Solakov, Masist Gül y Young-il Ko. Así mismo, en el contexto iberoamericano se pueden recordar exposiciones como la del artista Martín Vitaliti en el Museo ABC de Madrid (2013), las obras de Francesc Ruiz de «cómic expandido» expuestas en diversos museos y galerías de España y Europa, o el performance del colectivo argentino Un Faulduo, en el MACBA (2018), para citar solo algunos casos representativos ${ }^{25}$.

En este sentido, la inclusión del cómic en el 45SNA muestra un acercamiento similar a lo que los estudios recientes de cómic han explorado en el contexto norteamericano o europeo, al exponer la manera en que la historieta, proveniente de un campo cultural distinto del de las artes plásticas, trata de apropiarse de los espacios de exposición (museos, galerías, etc.) para legitimarse, sin acabar de conseguirlo completamente. La particularidad del caso colombiano radica en que, en un contexto en el que el cómic y la narración gráfica no tienen todavía la tradición industrial de otros países ni el conjunto de circuitos, prácticas y actores que lo delimitarían como un campo autónomo, la historieta ha encontrado en la apertura de las prácticas artísticas contemporáneas un terri-

\footnotetext{
24 La obra de Marshall tuvo una aparición previa en la versión número 53 de la Carnegie International 1999/2000 que expuso su pieza de cómic como papel de periódico en el Museo de Arte Carnegie (Pensilvania). Luego, la versión número 54 de la Carnegie International 2004/2005 invitó a Robert Crumb a hacer el cartel de la exposición e incluyó algunos de sus dibujos y tiras en las salas del museo. Así fue como el cómic se incorporó en una de las muestras de arte contemporáneo más antiguas del mundo.

25 En su artículo El cómic en los museos de arte. Retos museológicos y museográficos, Santos M. Mateos Rusillo ofrece otros ejemplos, así como un conjunto de claves y reflexiones de gran interés sobre la museografía de los cómics (Mateos Rusillo, 2021).
}

torio propicio para sus búsquedas, mostrando algunas de las líneas que se abren para este medio en la actualidad, más allá de su nicho editorial tradicional ${ }^{26}$.

A este respecto, el 45SNA permite ver el papel central que han tenido las propuestas curatoriales, a partir de las cuales se ha logrado recontextualizar obras de cómic no concebidas en sí mismas como obras de arte a ser expuestas en una museografía, llevándolas al espacio tridimensional y poniéndolas en diálogo con otras obras, relacionadas con el cómic de manera más indirecta, pero concebidas dentro de prácticas propias del arte contemporáneo.

\section{Bibliografía}

Barba Jacob, Porfirio. Canciones y elegías. México D.F.: Editorial Alcancía, 1932.

Barón, María S., Gabriela Pinilla y Camilo Ordoñez. De la vía armada a la vía láctea. Monos e historietas de Joe Broderick. Bogotá: Idartes, 2018.

Beaty, Bart. Comics versus Art. Toronto: University of Toronto Press, 2012.

Boltanski, Luc. «La constitution du champ de la bande dessinée». Actes de la recherche en sciences sociales, 1, 1975, pp. 3759, https://www.persee.fr/doc/arss_0335-5322_1975_ num_1_1_2448 Recuperado el 25 de enero de 2021.

Bordes, Enrique. Cómic, arquitectura narrativa. Madrid: Ediciones Cátedra, 2017.

Chalarka, Ulianov. Historia gráfica de la lucha por la tierra en la Costa Atlántica. Montería: Fundación del Sinú, 1985.

Conde, Juan A. «Del cómic a la novela gráfica. Mutaciones editoriales de la historieta colombiana en el siglo XXI». Mitologias Hoy. Revista de pensamiento, crítica y estudios literarios latinoamericanos, 20, 2019, pp. 61-77, https://doi.org/10.5565/ rev/mitologias.662 Recuperado el 21 de enero de 2021.

De Moya, Alvaro. «The first international: I Exposicao Internacional de Historias em Quadrinhos». Comic Art in Museums. Ed. Kim Munson. Jackson: University Press of Mississippi, 2020, pp. 98-103.

Fernández, Sandra. «TRansHisTor(ia) y su visualidad». El Espectador, 21 de octubre de 2019, https://www.elespectador.com/el-magazin-cultural/transhistoria-y-su-visualidad-article-887070/ Recuperado el 18 de enero de 2021.

\footnotetext{
${ }^{26}$ Aunque en la última década, el cómic colombiano ha encontrado otra forma de legitimación, integrándose al circuito del libro, a través del uso estratégico de la etiqueta «novela gráfica» (Conde, 2019).
} 
Foster, Hal. El retorno de lo real. Madrid: Akal, 2001.

García, Andrea y Diana Ojeda. «Conjurar el olvido: campesinos y política en las llanuras del Caribe colombiano en los años 70». Antípoda. Revista de antropología y arqueología, 31, 2018, pp. 137-141, https://doi.org/10.7440/antipoda31.2018.07 Recuperado el 24 de enero de 2021.

Gravett, Paul. Comics Art. Yale: Yale University Press, 2013.

Groensteen, Thierry. Comics and Narration. Jackson: University Press of Mississippi, 2013.

Kalmanovitz, Manuel. «Llamitas al viento». 45 Salón Nacional de Artistas, el revés de la trama. Catálogo. Bogotá: Ministerio de Cultura, República de Colombia, 2019, pp. 119-138.

Kalmanovitz, Manuel. «Llamitas al viento». Guía de uso. 45 Salón Nacional de Artistas, el revés de la trama. Bogotá: Ministerio de Cultura, República de Colombia, 2019, pp. 164-215.

«Lucas Ospina-Arquitecturas narrativas». Youtube, cargado por el 45 SNA, octubre 15 de 2019, https:/ / www.youtube.com/watch?v=A1GQZmVxAQ0.

Martín, Alejandro. «45 Salón Nacional de Artistas». 45 Salón Nacional de Artistas, el revés de la trama. Catálogo. Bogotá: Ministerio de Cultura, República de Colombia, 2019, pp. 13-43.

Martín, Alejandro. «Arquitecturas narrativas». 45 Salón Nacional de Artistas, el revés de la trama. Catálogo. Bogotá: Ministerio de Cultura, República de Colombia, 2019, pp. 161-193.

Martín, Alejandro. «Arquitecturas narrativas». Guia de uso. 45 Salón Nacional de Artistas, el revés de la trama. Bogotá: Ministerio de Cultura, República de Colombia, 2019, pp. 18-39.

Mateos Rusillo, Santos M. «El cómic en los museos de arte. Retos museológicos y museográficos». Eu-topias, Vol. 21, 2021, pp. 113-127.
Méon, Jean-Matthieu. «Comics Exhibitions in Contemporary France: Diversity and Symbolic Ambivalence». International Journal of Comic Art, 17, 2015, pp. 446-464.

Méon, Jean-Matthieu. «Comics in Museums and at their Periphery: Hierarchical Reaffirmation and Domination Adjustments in French Art Museums». ImageTexT: Interdisciplinary Comics Studies, 10, 2019, http://imagetext.english. ufl.edu/archives/v10_3/meon/ Recuperado el 26 octubre de 2020 .

Munson, Kim, ed. Comic Art in Museums. Jackson: University Press of Mississippi, 2020.

Munson, Kim. «Beyond High and Low: How Comics and Museums Learned to Co-exist». International Journal of Comic Art, 11, 2009, pp. 283-298.

Negrete, Víctor. «A la memoria del maestro Orlando Fals Borda: bases y desarrollo de la investigación-acción participativa en Córdoba (Colombia)». International Journal of Psychological Research, 1, 2008, pp. 85-97.

Quirion, Louise. What place for comics in museum exhibitions? Tesis de maestría, Dundee University, 2015-2016, http:// neuviemeart.citebd.org/IMG/pdf/dissertation_comics_ exhibitions.pdf Recuperado el 15 de enero de 2021.

Rappaport, Joanne y Víctor Negrete. «La IAP con las comunidades: el caso de los folletos ilustrados». Documentos para la reflexión, 10, 2015, pp. 37-44.

Rappaport, Joanne. «Visualidad y escritura como acción: Investigación Acción Participativa en la Costa Caribe colombiana». Revista Colombiana de Sociología, 41, 2018, pp. 133-156, https://doi.org/10.15446/rcs.v41n1.66272 Recuperado el 19 de enero de 2021. 